Journal of Contemporary Research in Business, Economics and Finance

ISSN: 2641-0265

Vol.1, No. 1, pp. 12-15

2019

Publisher: Learning Gate

DOI: 10.33094/26410265.2019.11.12.15

(C) 2019 by the authors; licensee Learning Gate

\title{
Controversies and Challenges of Islamic Banking: Analysis of Regulatory Reform
}

\author{
Tijjani Muhammad \\ Federal University, Gashua, Islamic Studies Department, Nigeria \\ Email: hajiteee@fugashua.edu.ng \\ Dani Mamman \\ University of Maiduguri, Islamic Studies Department, Nigeria \\ Mujitaba Abubakar Tangaza \\ Sokoto State Polytechnic, Marketing Department, Nigeria \\ Email: matangaza@gmail.com
}

Received: 27 June 2019; Revised: 31 July 2019; Accepted: 13 August 2019; Published: 29 August 2019

Abstract: Islamic bank has received a warm welcome since after 2009 financial crisis; the Islamic bank had been selected as an alternative to a conventional banking system. Despite its momentum growth, Islamic finance is covered with contemporary controversies and challenges in operation and regulatory reform. The paper advocates contemporary solutions that address these challenges.

Keywords: Controversies, Challenges, Islamic Banking, Regulatory reform

\section{Introduction}

Islamic banking is an economic and financial framework which operates based on principles of Shariah law, Islamic law prohibits the giving and acceptance of riba (Interest) on money borrowed and lent. However, not all Muslims believe that the Qur'an states impose such prohibition, some interpreted such ban on pre-Islamic practices which enslavement a lot of people. Nonetheless, the Riba prohibition remains fundamental. The emphasis on profit sharing (equity) and Loss sharing (risk) time controversial, the prevailing Shariah interpretation of financial instruments which are Shariah compliant.

\section{Controversies and challenges in Islamic finance}

It is obvious that Islamic finance has taken the financial world storm and also been recognized as a phenomenon that continued to record a growth within decades. However, the Islamic finance attracted the attention of global financial institution where developed and developing countries accepted its momentum. The unprecedented popularity accomplished based on interim of growth. According to Sheik (2007), the Islamic finance achieved a remarkable growth after the world financial meltdown, whereby international financial experts are interested in the dual financial system in different western countries around the world. All these are not free from some controversies and challenges encountered by the institution. The paper evaluates some certain issue of a fatwa and regulatory bodies which classified as controversial. 
The fatwa is a religious ruling giving by senior scholars on an issue related to Islamic law and backed by the legal opinion or learned interpretation (Ali, 2005). However, Fatwa basically related to matters that are unclear guidance from the Shariah perceptive (Qur'an and Sunnah). Fatwa under Islamic finance is required on matters which are uncertain and ambiguity on certain activities that are not in accordance with Shariah. However, the main issue faced by the fatwa as concerned there is no single authority that Islamic financial industries rely on and, no harmony among Shariah scholar in terms of ruling based on financial products. In all financial intermediaries have their Shariah Boards which consists numbers of scholars who were familiar with both financial and religious understanding (Shah and Hassan, 2015).

According to Lawai (1994), Fatwa shopping seems to be the threat to Islamic finance, that works against the fatwas harmonization, such required, in order to synchronize and reduced complexities in structuring products in terms of cost and that increases inconsistency between leading customers, investors, and Islamic products. However, such inconsistencies lead customers and investors in a stage of uncertain regarding Shariah-compliant products that eventually lead to losing faith in the Islamic finance industry. Moreover, the fatwa has a different interpretation on the relating Shariah rulings that happened due to the existence of the several sects in Islam, each sect relies on its authority or body which issued fatwa and interpretation on Shariah issues that makes it fairly complicated. Perhaps the interpretations of Shariah issues given by a certain sect which definitely differ with other sects stand and that would conflict such rulings and affect such products in terms of accepting or rejecting (SunGard, 2008). Furthermore, there is an organization of Accounting and Auditing Organisation for Islamic Financial Institutions (AAOIFI) which consistently reviewing issues related but lack of Islamic standardization and consensus between the religious sects (Karim, 2001).

Another issue faced by the Islamic financial Institution is a shortcoming of professionals in the field who have both experiences of conventional and Islamic financial system; such qualified professional can easily manipulate conventional products without paying attention to the unique rules and shariah consequence. The range number of Shariah scholar will be around 270-300 in the Industry which quite low compare to what is being expected. However, scholars are been criticised for accumulating millions of dollars and severe several institutions instead of concentrated on one financial institution (Alam, 2009).

Iqba and Molynenx (2005), the growth and development of Islamic financial institution has meant a lot to the system but the industry has not been able to produce enough experts to support the growth and development of the industry. However, many professionals are interested to work with industry but they have not had enough experience to support the industry competently to adjust and admonish on Islamic financial transactions, which lead to the shortage of Islamic finance expert and hence would probably affect the growth of the industry.

SunGard (2008) another challenge facing the Islamic finance industry Shariah Auditing, this area is significantly important, perhaps the attention is largely not given that identifies based on recognition from Islamic banks professionals and investors. Apparently, all Islamic financial institutionsare promptly in needs of Shariah audit that takes place at least once a year based on AAOIF.

Aioanei (2007) identify that the Islamic finance industry need to build a confidence in its customers as well as their operators to harmonize their market operations based on Shariah-compliant for the purpose of two sequential things first to be cleared by the Shariah board, the compatibility of the products. Secondly, to ensure that all transactions are compliant with the verdicts of the Shariah board, that will clearly differentiate the conventional structured products from the Islamic financial products.

Structured Islamic finance product which has recorded a momentum market and experiencing an explosive growth is Sukuk. In 2008, the Sukuk global market had more than doubled and that was impressive growth, however, the growth has slowed since the denomination of US dollar comes to the Sukuk market, and that signify two concerns over Sukuk (Series, 2012). Risk sharing and pricing, the concern over price with Ijara Sukuk and Mudarabah Sukuk, perhaps the Ijara Sukuk and the rate of return is based on rent while Mudarabah is profit sharing. However the concern here is the benchmarks 
SAIBOR, LIBOR or KIBOR that replicated conventional bond in interest rate, and that rate of return to Sukuk investors are competitive with those on conventional bonds (Siddiqui, 2006).

Risk Sharing: the return on investment based on risk sharing need to be justified, which the notion has to be taken on each other's burden, not like other financial industry are only channel it to the investor once is the default.Another challenge on the phenomenal growth of Islamic finance, the industry started to attract the attention of international players and many more industries, whereby the conventional banks started offering windows of the Islamic bank, that would surely jeopardise the Islamic finance strength in their products and services (Khan and Bhatti, 2008). The AAOIFI and IFSB as regulators should establish a standard point to resolve the issue of standardization of such windows in the conventional banking system (Ainely, 2007). Moreover, the lack of standard body promulgating financial contracts and the shariah law perspective that categories the varies permissibility in the industry and hence the controversial issues in the system for instance, the sales of debt (bai-i-dain) the majority of scholars disallowed and subsequently, some of the prominent Shariah scholars said almost $85 \%$ of Sukuks in the market are not Shariah-compliant (Lahsasna and Lin, 2012).

Another challenge faced by the Islamic finance lack of skilled operator both in the Shariah board as well as the operational level that led to the major snag behind and low penetration in the market (Mahdi, 2016).Islamic prudential regulators, the Islamic banks need to be supervised, lack of effective supervision is one of the weaknesses of the institution such as leasing prudential regulators are applied to Ijara and transfer to Musharakah where the nature of these products are not the same entity (Mohammad, 2009).

While the conventional system has harmonized and approved their regulatory standard the Islamic bank there are no approved standards so far for Islamic banking, they follow some of the conventional regulations not completely to adjust their existence. For the capital structure is totally different with the conventional banking system (Ahmad, Osmani and Kasim, 2010).

\section{Solution to Islamic Bank}

The industry needs to understand that these challenges would constantly remained if the regulatory is not separated from the conventional system, for instance, Bahrain, Malaysia, and Oman have developed and separate framework to Islamic bank by banning Islamic windows from conventional branches (Kammer, Norat, Pinon, Prasad, Towe and Zeidane, 2015).

In other countries, for instance, Turkey and United Arab Emirate (UAE) are promoting Islamic finance to becoming Centres of Excellent, however, they have been working isolated rather collectively to overcome problems as a result of lack of clear strategy and potential direction for the institution. Establish Global Shariah board to ensure professionalism among Shariah experts in the field of Islamic finance (Temporal, 2011). However, the Islamic finance industry needs to focus on the development of products and attracts investors and entrepreneurs that would foster the market integration and momentum attraction in the market. Futhermore, as Shariah opinion diversified, in a situation where shariah school of thought may approve as shariah compliant and another school of thought rejected, the global central board would be in a better position to achieve harmony at the global level with a representative within all schools of thought (Bhavini and Saad, 2017).

\section{Conclusion}

Islamic banking system is becoming a strong industry in the developed and developing countries around the globe since after financial crisis 2009. And that was being recognised by their conventional counterparts. However, the industry is facing underpinning struggles in the process and unique sets of challenges which were discussed above.

Moreover, the Islamic banking is not to replicates of a conventional system rather rendering services to people in demand in Islamic ways and to innovate new products to promote the growth of Islamic finance and resolve the controversies and challenges of the industry. 


\section{References}

Ahmad, A. U. F., Osmani, N. M., \& Karim, M. F. (2010). Islamic finance in Australia: The Potential problems and prospects. Abdul Ghafar Ismail Mohd Ezani Mat Hassan Norazman Ismail Shahida Shahimi, 219.

Aioanei S., (2007) European Challenges for Islamic Banks. The Romanian Journal, 10. 25. 7-20

Alam, M. S. (2009). Islamic finance: An Alternative to the Conventional Financial System?. Korea Review of International Studies, 37-53.

Iqbal M. \& Molyneux P., (2005), thirty years of Islamic Banking: History performance and prospects. Islamic Economic 19, 1, 37-39

Kammer, M. A., Norat, M. M., Pinon, M. M., Prasad, A., Towe, M. C. M., \& Zeidane, M. Z. (2015). Islamic finance: Opportunities, challenges, and policy options (No. 15). International Monetary Fund.

Karim, R. A. A. (2001). International accounting harmonization, banking regulation, and Islamic banks. The International Journal of Accounting, 36(2), 169-193

Lahsasna, A., \&Lin, L. S. (2012), Issues in Islamic capital markets: Islamic bond/Sukuk. In 3rd International Conference on Business and Economic Research (3rd ICBER 2012) Proceeding (pp. 495-512).

Lawai H., (1994) Key features in Islamic Banking. Journal of Islamic Banking and Finance, 11.4.7-13

Mahdi, S. S. (2016). Determining why there is a Slow Uptake of Islamic Microfinance Products in Kenya (2015) (Doctoral dissertation, United States International University-Africa).

Mohammad, M. T. T. H. (2009). Alternative development financing instruments for waqf properties. Malaysian Journal of Real Estate, 4(2), 45

Shah, S. M., \& Hassan, M. S. (2015). Shariah Committee, Shariah Governance in Islamic Financial Institutions. Issues in Contemporary Accounting E Finance, 111.

Sheik S.A (2007), Critical Analysis of current Islamic Banking System www.accountancy.com. Pk

Siddiqui M.N (2006) Islamic Banking and Finance in theory and practice: A survey of the state of the art, jedda Journal of Islamic Economic studies, Islamic research and training institution, Islamic Development bank.

SunGard (2008) Islamic Banking and Finance-Growth and Challenges a head. www.sungard.com

Temporal, P. (2011). Islamic branding and marketing: Creating a global Islamic business. John Wiley \& Sons. 